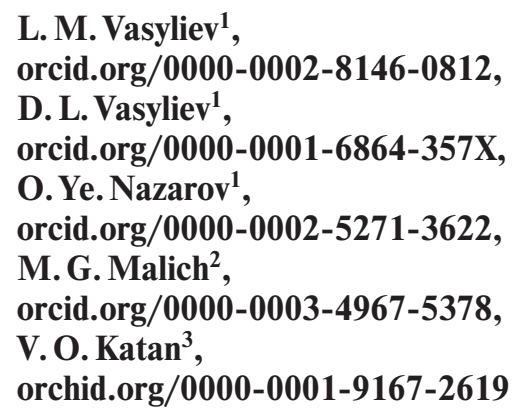

1 - Institute of Geotechnical Mechanics named by N. Poljakov of National Academy of Sciences of Ukraine, Dnipro, Ukraine

2 - National Metallurgical Academy of Ukraine, Dnipro, Ukraine, e-mail: n22051957m@gmail.com

3 - Oles Honchar Dnipro National University, Dnipro, Ukraine

\title{
THE METHOD FOR DETERMINING THE PARAMETERS OF THE DIAGRAMS OF A TRUNCATED-WEDGE DESTRUCTION OF CYLINDRICAL SAMPLES OF ROCKS
}

Purpose. Development of an analytical method for calculating the parameters of complete diagrams "longitudinal tension deformation" for the truncated-wedge shape of destruction of cylindrical rock samples to control the stress-strain state of the rock mass and effective destruction of these materials during disintegration.

Methodology. Analytically, by developing a mathematical model of the fracture process of cylindrical rock samples with their truncated-wedge form of crack development, an algorithm is created for calculating the full deformation diagram from the acting tension using the experimental values of four indicators of material properties - the shear resistance limit, internal and external friction coefficients and elastic modulus. The method is based on the improved Coulomb strength criterion, supplemented by the parameters of contact friction and allowing one, using the theory of slip lines, to calculate the limiting state of the material at the tip of cracks developing from the edges of the sample of the correct geometry, taking into account the release of part of the material from the load and compliance with Hooke's law deformation of the sample bearing area and the specific force on it.

Findings. The method of mathematical modeling makes it possible to determine the ultimate strength and residual strength of cylindrical rock samples using four property indicators that can be experimentally established by simple methods.

Originality. For the first time, analytical modeling of the process of destruction of cylindrical rock samples with their truncated-wedge form of destruction was carried out, taking into account the internal contact friction depending on the properties of the rock material and external contact friction.

Practical value. The proposed method of mathematical modeling and the calculation algorithm make it possible to determine the limit and residual strength of rock samples using four property indicators, which can be established experimentally by simple methods under laboratory conditions of enterprises of the mining and metallurgical complex. The calculation results can be quickly used to control the state of the rock mass and effective destruction upon disintegration.

Keywords: mathematical modeling, rock; tensile strength, destruction, crack, complete tension-strain diagram

Introduction. One of the most important tasks in the development of minerals by the mine method is the stability of the rock mass in the bottomhole space. In addition, a very important task in the preparation of charge and building materials is to increase the efficiency of crushing and shattering of rock mass.

During the operation of underground mine workings, when controlling rock pressure, production workers are forced to allow significant destruction of rocks in the delineating massifs within the limits of their safe bearing capacity. As you know, the bearing capacity is characterized by certain values of tension and deformations, first of all, by residual strength, the determination of which is not available due to the variability of the stress-strain state of rock massifs in the process of mining. Therefore, the parameters of the bearing capacity are estimated by calculation methods using diagrams "longitudinal tension - longitudinal deformation" taken by laboratory experiments on special presses of rock samples corresponding to the operating conditions of the development workings.

Therefore, to control the stress-strain state of the rock mass and their effective destruction during disintegration, it is necessary to predict with high reliability the strength and deformation properties of the rock not only when loaded to the ultimate strength, but also in the transcendental region of deformation, it is necessary to foresee the paths of crack development and residual resistance breeds.

(C) Vasyliev L. M., Vasyliev D. L., Nazarov O. Ye., Malich M. G., Katan V. O., 2021
Important information characteristics necessary to control the stress-strain state of the rock mass and their effective destruction during disintegration involve the ultimate strength and residual strength of the samples, determined from the diagrams "longitudinal tension - deformation" of their out-oflimit destruction [1-4]. Prismatic or cylindrical samples are used for experimental construction of "longitudinal tension strain" diagrams. Since the 60s of the last century, these characteristics have been taken on special presses that are available in separate research institutes, for example, at the Institute of Geotechnical Mechanics of the National Academy of Sciences of Ukraine, Kryvyi Rih National University [1], St. Petersburg Mining University [2], far abroad [3-5]. At the Institute of Geotechnical Mechanics and Kryvyi Rih National University, tests are carried out on cubic samples, at St. Petersburg Mining University - on cylindrical samples, in the far abroad on cubic and cylindrical samples.

However, these works require highly qualified personnel, and the equipment is located far from the consumer, where the operational information about the properties of rocks is needed.

Therefore, there is a need to develop an analytical method for calculating the limits and residual strength of samples with knowledge of the parameters of the properties of rocks, determined by simple methods available for mining enterprises. Earlier attempts were made to mathematical modeling of the processes of destruction of samples [6, 7]. However, these models have not been brought to the level of completed analytical methods for calculating the parameters of the diagrams normal tension - longitudinal deformation of the ultimate failure of rock samples. These articles consider the problem of de- 
struction of rock samples using the experimental HawkeBrown criterion. An extensive review of the use of this criterion by many authors for uniaxial and volumetric compression is given. To determine the strength, the authors assume that fracture occurs along the deviatorial plane, and not along the plane of maximum tangential stresses according to Coulomb. Along the way, we note that the Coulomb criterion is confirmed on plastic and brittle materials, since it follows from the equations of the limiting state. Therefore, it can reasonably be applied.

In the work [8], the author gives an assessment of the influence of contact conditions on the values of the limiting parameters, which can be used in the development of analytical methods for calculating the parameters of diagrams. The article also provides a method for calculating the limiting state of a specimen under uniaxial compression. Judging by the design scheme, the authors apply the Coulomb strength criterion in the presence of contact friction. But the lateral sides of the sample are taken as rectilinear. In our opinion, in this case, the rule of shear stresses in the corner regions is inapplicable. The article [9] provides a rationale for the formation of a barrelshaped form due to inhibition of transverse deformation by contact friction between the press plate and the sample. Moreover, the authors come to the conclusion that tensile stresses do not appear at any point in the sample; the sample is compressed in all directions. We should agree with this.

It follows from this concept that in the presence of contact friction, the mathematical model should provide for the barrel formation of the lateral surfaces of the sample, which ensures the application of the rule of pairing of tangential stresses in the corner regions during its deformation and destruction. In [10], the authors give the position of the boundary of the zone of complete contact and slip. Based on this, they argue that the crack does not form at the corner point, but at the point that is the boundary of the full contact and slip zones. However, the confirmation of this position is not convincing enough, since the experiments were carried out by the authors in the presence of a crack in the samples. Analytical plotting methods for prismatic samples are detailed in article [11] and in book [12].

Perhaps more widely than prismatic samples, cylindrical samples from well core drilling are used to determine experimental longitudinal tension-strain diagrams. Therefore, it becomes necessary to develop methods for calculating the parameters of the above diagrams for cylindrical samples.

Methodology. It is known that during uniaxial compression of cylindrical specimens, a truncated-wedge form of its destruction is formed (Fig. 1) - the most common of the five generally known.

To describe the process of destruction of rocks, the Coulomb criterion is widely used - the maximum effective shear tensions on slip lines, more precisely on slip surfaces (SS). The Coulomb criterion for cohesive media is based on the assumption that the shear resistance of the rock $\tau_{\alpha}$ on an inclined area of the SS is equal to the sum of the pure shear resistance (ultimate shear strength) and a value proportional to the normal tension $\sigma \alpha$ on this area (positive compression), from internal friction.

$$
\left|\tau_{\alpha}\right|=k_{n}+\mu \sigma_{\alpha}
$$

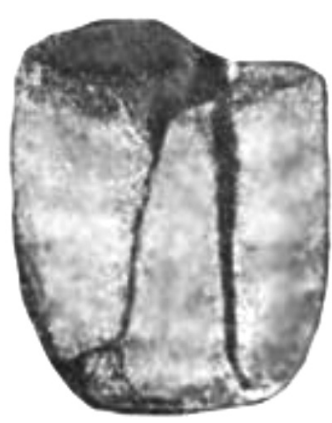

Fig. 1. Experimental truncated-wedge shape by A. I. Baron

$$
\tau_{e} \geq k_{n}=\left|\tau_{\alpha}\right|-\mu \sigma_{\alpha},
$$

where $\tau_{e}$ is effective shear tensions on SS.

Inequality (2) should be understood as follows: destruction occurs if the left side is larger than the right side on the SS. Upon fracture, a crack forms on the SS. Knowing, according to the plane deformation model, the values of the coordinates of the tip of one or two cracks at each moment, it is possible to determine the bearing part of the sample material, which is equal to the initial area of the latter minus the part released from the load during the crack propagation along the SS. The part of the specimen released from the load is determined by the values of the abscissa of the crack tip as $x=y \cdot \operatorname{ctg} \alpha$, where $\mathrm{y}$ is the ordinate of the $O Y$ axis, $\alpha$ is the angle of inclination of the SS at the crack tip relative to the abscissa axis $x$. Knowing the tensions $\sigma y$ at the crack tip, its coordinates and the regularities of the distribution function of contact tensions on the part that did not come out of the load - the bearing part of the specimen, it is possible to determine the ultimate strength during crack propagation in the presence of values of three property indicators - shear strength $k_{n}$, coefficients external $f_{c}$ and internal $\mu$ friction. Taking into account the symmetry of the semicircles of the cross-section of the cylindrical sample, the calculation is performed for one of them, for example, the left one. Then the specific force on the bearing part of the sample

$$
p=\sigma_{y} \frac{S_{0}-\left(\int_{0}^{x} F(x) d x+\frac{2 f_{c}}{h} \int_{0}^{x} F(x) x d x\right)}{S_{0}-\int_{0}^{x} F(x) d x},
$$

where $\sigma_{y}$ is crack tip normal tension; $S_{0}$ is the original semicircle area; $\int_{0}^{x} F(x) d x$ is an element of the area of a semicircle emerging from the load at the moment of crack formation; $f_{c}$ is the contact friction coefficient; $u$ is the circle diameter; $h$ is sample height; $x$ is abscissa of the point under consideration.

Subsequently, a physical explanation of formula (3) will be given. The amount of deformation is determined by dividing the value of the specific force by the modulus of elasticity of the rock

$$
\varepsilon=\frac{p}{E}
$$

It is assumed that Hooke's law is observed at the crack tip. The ultimate strength on the transcendental branch of the "longitudinal tension - deformation" diagram is determined by the formula

$$
\sigma=\frac{p S_{i}}{S_{0}}
$$

where $S_{i}$ is the area of the part of the circle that does not go beyond the load.

Let us demonstrate the process of sample destruction in the diagram [12], for convenience of consideration - in an inverted form in comparison with Fig. 1. The center of the coordinate axes is located in the upper left corner of the sample.

In the upper quarter of the left longitudinal half of the sample, the contact $\tau_{c}$ and internal $\tau_{y x}$ shear tensions have a positive sign, and in the lower quarter, they are negative. On the right half, the signs have opposite meanings. The truncated-wedge form of destruction of rock samples is characterized by the absence of intersection of the SS with the vertical plane of symmetry. In the upper quarter of the left longitudinal half of the sample, the contact $\tau_{c}$ and internal $\tau_{y x}$ shear tensions have a positive sign, and in the lower quarter, they are negative. On the right half, the signs have opposite meanings.

The truncated-wedge form of destruction of rock samples is characterized by the absence of intersection of the SS with the vertical plane of symmetry. Since the lateral surfaces of the 
specimen acquire a convex shape due to deformation, we apply the rule of pairing of tangential tensiones at the corner points. We assume that deformations develop in pairs along the SS: on the left along the SS $\xi_{l}$ and on the right along the SS $\xi_{r}$.

Taking into account the symmetry of the SS, we describe the formation of the left SS $\xi_{l}$.

As can be seen from formula (3), for the calculation it is necessary to have calculation formulas for tensiones at the crack tip at the moment of its formation

In addition, as follows from this formula for its solution, it is necessary to know the regularity of the distribution of contact normal tensiones, for which we use the L. Prandtl model for a prismatic specimen of unit width [12]

$$
\sigma_{y i}=\sigma_{y 0}\left(1+\frac{2 f_{c} x}{h}\right)
$$

where $\sigma_{y 0}$ is the vertical normal tension at the corner point of the sample.

Now you should bind the formula (6) to the area of the cylinder. It is important to develop a mathematical model for the distribution of contact normal tensiones similar to L. Prandtl's formula for prismatic samples. In contrast to a prismatic specimen, in which the width of the sliding plane is kept constant, in a cylindrical specimen this plane is constantly expanding. We tried several models, but they did not give satisfactory results. Let us describe the proposed approach for calculating the parameters of the sample diagrams.

Results. First of all, we write the formula for the circumference of a cylinder in the $x-y$ coordinate system (Fig. 2).

$$
(x-r)^{2}+y^{2}=r^{2},
$$

where $r$ is the cylinder circle radius.

From the transformation of formula (7) we have

$$
y=\sqrt{2 r x-x^{2}} .
$$

Then the formula for the chord length of a segment is

$$
a=2 \sqrt{u x-x^{2}},
$$

where $u=2 r$.

Then, using expressions (6) and (8), we write down the formula for the distribution of the vertical tension on the contact surface of the cylindrical sample, while linking the abscissa $x$ (and hence length of a segment $a$ ) to the left SS $\xi$

$$
\sigma_{y i}=\sigma_{y 0}\left(\frac{a_{\xi}}{u}+\frac{2 f_{c} x_{\xi} a_{\xi}}{u h}\right) .
$$

According to expression (3), let us write the formula for the force of action on the part of the specimen that emerges from the load at the moment of crack development in the form

$$
P=\sigma_{y} \int_{0}^{x}\left(\frac{a_{\xi}}{u}+\frac{2 f_{c} x_{\xi} a_{\xi}}{u h}\right) d x,
$$

where $\sigma_{y}$ is crack tip normal tension.

Now, using tables of integrals, we solve the integral of the formula (10)

$$
P=2 \sigma_{y}\left(\left(\frac{a_{\xi}}{8 u} A-\frac{1}{8 u} B\right)+\frac{2 f_{c}}{u h}\left(-\frac{a_{\xi}^{3}}{24}+\frac{a_{\xi}}{16} A-\frac{1}{16} B\right)\right) .
$$

Where

$$
A=\left(2 x_{\xi}-1\right) \text { and } B=\left(\frac{\pi}{2}-\arcsin a_{\xi}\right) .
$$

To determine the specific force on the contact plane during crack development (beyond the limit elasticity), the force value should be divided by the value of the area coming beyond the load. Then, on the basis of expression (11), in accordance with formula (3), we find the value of the specific force on the bearing part of the sample, equal to $\frac{\pi u^{2}}{8}$, (the area of the semicircle) minus the area released from the load during the crack propagation.

$$
P=\frac{\sigma_{y} \frac{\pi u^{2}}{8}\left(\frac{a_{\xi}}{8 u} A-\frac{1}{8 u} B+\frac{2 f_{c}}{u h}\left(-\frac{a_{\xi}^{3}}{24}+\frac{a_{\xi}}{16} A-\frac{1}{16} B\right)\right)}{\frac{\pi u^{2}}{8}-\left(\frac{a_{\xi}}{8 u} A-\frac{1}{8 u} B\right)} .
$$

For a complete solution of the problem, it is necessary to determine the normal tension $\sigma_{y}$ at the crack tip. In [11, 12], a method for determining this tension based on the Coulomb criterion with allowance for contact friction is presented. The tensions $\sigma_{y}$ at the crack tip on the SS $\xi_{l}$ according to the method are determined by the system of equations.

$$
\sigma_{y}=\frac{1}{\mu}\left[\frac{k_{n} \cdot(1+C) \cdot \exp \left(2 \mu\left(\beta_{\xi}-\beta_{b}\right)\right)}{1-C}-k_{b}\right],
$$

where

$$
\begin{gathered}
C=\sin \rho \sqrt{1-b_{\xi}^{2}} ; \\
k_{b}=\frac{\left(k_{n}+\mu \sigma_{y}\right)(1-C)}{(1+C) \cdot \exp \left(-4 \mu \beta_{b}\right)} ; \\
b_{\xi}=\frac{f_{c}\left(1-\frac{2 y}{h_{1}}\right) \cdot \sigma_{y_{\xi}}\left(1+\frac{2 f_{c}}{h} x_{\xi}\right)}{k_{n}+\mu \sigma_{y_{\xi}}\left(1+\frac{2 f_{c}}{h} x_{\xi}\right)} ; \\
b_{b}=\frac{f_{c} \cdot \sigma_{y_{\xi}}\left(1+\frac{2 f_{c}}{h} x_{b}\right)}{k_{n}+\mu \sigma_{y_{\xi}}\left(1+\frac{2 f_{c}}{h} x_{b}\right)} ; \\
\beta_{\xi}=\frac{1}{2} \operatorname{arctg} \frac{b_{\xi} \cos \rho}{\sin \rho-\sqrt{1-b_{\xi}^{2}}} ; \\
\beta_{b}=-\frac{1}{2} \operatorname{arctg} \frac{b_{b} \cos \rho}{\sin \rho-\sqrt{1-b_{b}^{2}}},
\end{gathered}
$$

where $k_{b}$ is effective shear tension at exit point $b \mathrm{SS} \xi$ on the contact surface; $x_{b}$ is point abscissa $b ; \beta_{\xi}$ and $\beta_{b}$ are angles of rotation SS $\xi_{/}$at the crack tip and at point $b$, respectively.

The angle of inclination of the SS $\xi_{l}$ is determined by the formula

$$
\alpha_{\xi}=\frac{\pi}{4}+\frac{\rho}{2}+\beta_{\xi},
$$

where $\rho=\operatorname{arctg} \mu$ is the internal friction angle.

Based on formula (11) using expressions (3-5) and (1219), we determine the values of the specific force on the bearing part of the sample. Knowing the values of the specific force, it is possible, using formula (4), to determine the current values of deformations in the process of crack propagation one of the parameters of the "longitudinal tension - deformation" diagram under uniaxial compression of samples. Now it is necessary to determine the values of the second parameter the current value of the specimen strength on the transcendental branch. To do this, the values of the specific force must be multiplied by the ratio of the bearing area emerging from the load inside the semicircle to the initial area of the latter according to expression (5). The multiplication of these parameters should provide an initial tension value equal to the specific force value and a decrease in strength on the transbound- 
ary branch of the diagram. To do this, we express the area emerging from the load in the form of a segment (Fig. 2), using the well-known formula

$$
S_{\text {ambd }}=\frac{u^{2}}{8}(\varphi-\sin \varphi) .
$$

The angle $\varphi$ is found from the expression

$$
\varphi=2 \arcsin \sqrt{1-\left(\frac{u-2 x_{\xi}}{u}\right)^{2}} .
$$

Then the area of the segment $a b v$ (Fig.2) in the process of crack development is

$$
S_{a b v}=\frac{u^{2}}{8}(\varphi-\sin \varphi)=\frac{u^{2}}{4}\left(\arcsin D-\left(1-2 x_{\xi}\right) D\right) .
$$
dians.

Where $D=2 \sqrt{u x_{\xi}-x_{\xi}^{2}}$ and the angle $\varphi$ is measured in ra-

Then the bearing area of the sample semicircle is

$$
S_{1}=\frac{\pi u^{2}}{8}-\frac{u^{2}}{4}\left(\arcsin D-\left(1-2 x_{\xi}\right) D\right) .
$$

Now, taking into account the fact that the area of the semicircle is equal to $\pi u^{2 / 8}$, we write the strength formula on the transboundary branch of the "longitudinal tension - deformation" diagram according to expressions (3) and (5), taking into account formulas (12-21), finally in form

$$
S_{1}=\frac{8 p}{\pi u^{2}}\left(\frac{\pi u^{2}}{8}-\frac{u^{2}}{4}\left(\arcsin D-\left(1-2 x_{\xi}\right) D\right)\right)
$$

According to formulas (3-5) using expressions (12-19) and (22), it is possible to determine the parameters of the true and conditional "longitudinal tension - deformation" diagrams by the method of iterations on a PC, which researchers obtain on presses with a truncated-wedge shape fracture of cylindrical specimens as a function of the transcendental branch $\sigma_{c}=\varphi(\varepsilon)$. Fig. 3 shows these functions for the value of the elastic modulus $E=2000 \mathrm{MPa}$ and different values of the rock properties for the sample with the height and diameter equal to one. An important conclusion should be drawn from the analysis of the diagrams: the slope of the transcendental curve $\sigma_{c}=\Psi(\varepsilon)$, the so-called decay modulus $M$, taken by researchers as a constant material characteristic similar to the elastic modulus $E$, depends on the numerical values of rock properties and is not constant. To confirm the conclusion, we show branch 5 at $f_{c}=0$ in Fig. 3. Many authors explain the roundness of the out-of-limit branches immediately beyond the elastic limit by the plasticity of rocks. In our opinion, this roundness is generated by contact friction. Rocks are classified as materials of increased fragility. The statement about their plastic state at low loads is not substantiated by anything.

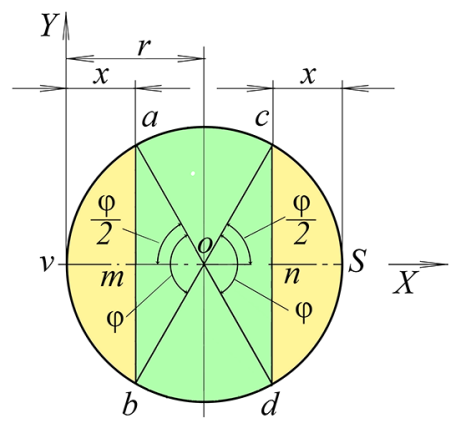

Fig. 2. Scheme of the formation of the bearing area during the development of two symmetric cracks

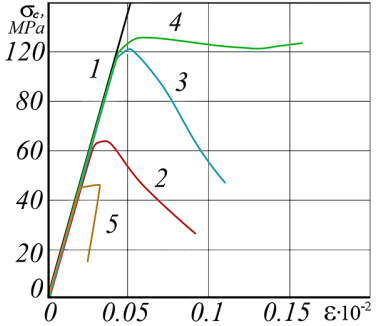

Fig. 3. Tension-deformation diagrams for the truncated-wedge forms of destruction of a cylindrical sample with a diameter and height, equal to one:

1 - true and conditional for: $f_{c}=0.25$ and $\rho=45^{\circ} ; 2-k_{n}=$ $=10 \mathrm{MPa} ; 3-k_{n}=15 \mathrm{MPa} ; 4-$ for: $f_{c}=0.25, \rho=50^{\circ}$ and $k_{n}=$ $=15 \mathrm{MPa} ; 5-$ for: $f_{c}=0, \mu=1.0$ and $k_{n}=10 \mathrm{MPa}$

Now the calculated tension - longitudinal deformation diagrams are comparable with the experimental ones. To confirm the reliability of the calculation of the exorbitant curves, we will borrow four experimental diagrams of tension - longitudinal deformation (Fig. 4) from the books by prof. A. N. Stavrogin. The authors do not give the necessary physical and mechanical characteristics - the shear limit of the material, the coefficients of external and internal friction. They can presumably be established by the outward appearance of the out-oflimit curves, while it is possible to achieve a fairly high agreement between the calculated and experimental ultimate strength.

Comparison of the calculated diagrams with the experimental ones obtained under uniaxial compression testifies to the high efficiency of the proposed method for constructing the out-of-limit curves of rock failure.

So, experimental diagram 2 corresponds to the experimental diagram 1 at $k_{n}=10 \mathrm{MPa}, \mu=1.0, f_{c}=0.4, E=3.5 \cdot 10^{4} \mathrm{MPa}$, calculated diagram $4-$ to experimental diagram 3 at $k_{n}=$ $=33 \mathrm{MPa}, \mu=0.808, f_{c}=0.15, E=5.1 \cdot 10^{4} \mathrm{MPa}$; calculated diagram 6 - to experimental diagram 5 at $k_{n}=28 \mathrm{MPa}, \mu=$ $=0.8391, f_{c}=0.1, E=3.1 \cdot 10^{4} \mathrm{MPa}$.

The long so-called tails of the transboundary branches arise from the action of contact friction. It is also important to note that there is an analogy of the schemes with a natural destroyed sample (Fig. 1). Calculations show that the truncatedwedge form of destruction is formed at $\rho>39^{\circ}$ and $f_{c}$ in the range of $0.02-0.4$

Conclusions.

1. For the first time, an analytical method was developed for determining the parameters of complete "longitudinal tension-deformation" diagrams for the truncated-wedge shape of fracture of cylindrical rock samples using four experimental characteristics $\left(k_{n}-\right.$ shear strength, $f_{c}$ and $m$ - coefficients of contact and internal friction, $E$ - modulus of elasticity) available for determination in mining laboratories. The advantage of the method is the efficiency of its use in a production environment.

2. The method is based on the improved Coulomb strength criterion, supplemented by the parameters of contact friction and allowing one, using the theory of slip lines, to calculate the limiting state of the material at the tip of cracks developing

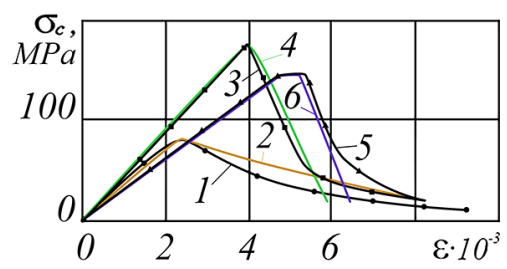

Fig. 4. Tension-longitudinal deformation diagrams with a truncated-wedge-shaped fracture 
from the edges of a sample of correct geometry, taking into account the release of a part of the material from the load and compliance with Hooke's law of deformation of the sample bearing area and the specific force on it.

3 . The developed method for determining the parameters of the normal tension - longitudinal deformation diagrams for the truncated-wedge form of destruction of cylindrical rock samples is recommended to be used at mining enterprises to determine the strength of rocks. The truncated-wedge form of destruction of samples is formed at $\rho>39^{\circ}$ and $f_{c}$ in the range of $0.02-0.4$.

4. The modulus of decay $M$ of the function of the transboundary branch $\sigma_{c}=\varphi(\varepsilon)$ of the diagrams, taken by researchers as a constant characteristic of the material, similarly to the modulus of elasticity $E$, depends on the numerical values of the indicators of the physical and mechanical properties of rocks and is not a constant of the material.

5. The roundness of the out-of-limit branches $\sigma_{c}=\varphi(\varepsilon)$ immediately beyond the elastic limit, taken by some authors for the state of plasticity of brittle rocks, is other than that. The roundness of the branches is caused by contact friction.

References.

1. Nesmashnyi, Y.A., \& Bolotnikov, A. V. (2017). Determination of rock strength using modern equipment on the example of the Bolshaya Glivatka deposit. Metallurgicheskaya i gornorudnaya promyshlennost, 3, 82-87.

2. Tarasov, B., \& Potvin, Y. (2013). Universal criteria for rock brittleness estimation under triaxial. International Journal of Rock Mechanics and Mining Sciences, 59, 57-69. https://doi. org/10.1016/j.ijrmms.2012.12.011.

3. Manouchehrian, A., \& Cai, M. (2016). Simulation of unstable rock failure under unloading conditions. Canadian Geotechnical Journal, 53, 22-34. https://doi.org/10.1139/cgj2015-0126.

4. Zhao, G., \& Cai, M. (2015). Influence of specimen heightto-width ratio on the strainburst characteristics of Tianhu granite under true-triaxial unloading conditions. Canadian Geotechnical Journal, 5, 890-902. https://doi.org/10.1139/cgj2014-0355.

5. Er. Kamaljit Kaur, \& Dr. Vishwas Sawant (2016). Comparison of rock samples from two different states. International Journal of Recent Research Aspects, 3, 25-28.

6. Bingxiang, H., \& Jiangwei, L. (2013). The effect of loading rate on the behavior of samples composed of coal and rock. International Journal of Rock Mechanics and Mining Sciences, 61, 23-30. https://doi.org/10.1016/i.ijrmms.2013.02.002.

7. Feiying Ma, Yongqing Wang, Haitao Li, Lin Wang, Hui Wang, \& Rui Jiang (2014). Staged Coalbed Methane Desorption and the Contribution of Each Stage to Productivity. Chemistry and Technology of Fuels and Oils, 50(4), 344-353.

8. Lokshina, L. Ya., \& Kostandov, Yu.A. (2014). Calculation of the limiting state of a rock sample under uniaxial compression with rigid stamps. Deformirovaniye i razrusheniye materialov s defektami i dinamicheskiye yavleniya $v$ gornykh porodakh $i$ vyrabotkakh, 108-112.

9. Trofimov, V. A., \& Filippov, Yu. A. (2015). Deformation and destruction of materials with defects and dynamic phenomena in rocks and mining. Deformirovaniye i razrusheniye obraztsa gornoy porody, 192-198.

10. Kostandov, Yu. A., \& Lokshina, L. Ya. (2015). Calculation of position of boundaries of full contact and slippage at compression of the samples of brittle materials. Deformirovaniye $i$ razrusheniye materialov s defektami i dinamicheskiye yavleniya $v$ gornykh porodakh $i$ vyrabotkakh, 74-78.

11. Vasyliev, L. M., Vasyliev, D. L., \& Usov, O. A. (2013). Analytical construction of "stress-strain" diagrams of rock samples with their truncated-wedge fracture. Metallurgicheskaya $i$ gornorudnaya promyshlennost, 6, 81-84.

12. Vasyliev, L. M., Vasyliev, D. L., Malich, N. G., \& Angelovskiy, A.A. (2018). Mechanics of formation of forms of destruc- tion of rock specimens during their compression: monograph. Dnipro: IMA-press.

\section{Метод визначення параметрів діаграм усічено-клинового руйнування циліндричних зразків гірських порід}

\author{
Л. М. Васильєв ${ }^{1}$, Д. Л. Васильєв ${ }^{1}$, О. С. Назаров ${ }^{1}$, \\ М.Г. Маліч ${ }^{2}$, В.О. Катан ${ }^{3}$
}

1 - Інститут геотехнічної механіки імені М. С. Полякова НАН України, м. Дніпро, Україна

2 - Національна металургійна академія України, м. Дніпро, Україна, e-mail: n22051957m@gmail.com

3 - Дніпровський національній університет імені О. Гончара, м. Дніпро, Україна

Мета. Розробка аналітичного методу розрахунку параметрів повних діаграм «поздовжнє напруження - деформація» для усічено-клинової форми руйнування циліндричних зразків породи для управління напруженодеформованим станом гірського масиву та ефективного руйнування цих матеріалів при дезінтеграції.

Методика. Аналітично, шляхом розробки математичної моделі процесу руйнування циліндричних зразків гірських порід при їх усічено-клиновій формі розвитку тріщин, створити алгоритм розрахунку повної діаграми деформування від чинного напруження 3 використанням експериментальних значень чотирьох показників властивостей матеріалів - межі опору зрушенню, коефіцієнтів внутрішнього й зовнішнього тертя та модуля пружності. В основу методу покладено вдосконалений критерій міцності Кулона, доповнений параметрами контактного тертя, що дозволяє, із використанням теорії ліній ковзання, проводити розрахунок граничного стану матеріалу у вершині тріщин, які розвиваються з країв зразка правильної геометрії з урахуванням виходу частини матеріалу 3-під навантаження, та відповідності закону Гука деформації несучого майданчика зразка з питомим на нього зусиллям

Результати. Метод математичного моделювання дозволяє визначити межу міцності й залишкову міцність циліндричних зразків гірських порід з використанням чотирьох показників властивостей, що простими способами можуть бути встановлені експериментально.

Наукова новизна. Уперше проведено аналітичне моделювання процесу руйнування циліндричних зразків гірських порід при їх усічено-клиновій формі руйнування $з$ урахуванням внутрішнього тертя, що залежить від властивостей матеріалу породи й зовнішнього контактного тертя.

Практична значимість. Запропонований метод математичного моделювання та алгоритм розрахунку дозволяють визначити межу й залишкову міцність зразків гірських порід з використанням чотирьох показників властивостей, що можуть бути встановлені експериментально в умовах лабораторій підприємств гірничо-металургійного комплексу. Результати розрахунку можуть бути оперативно використані для управління станом гірського масиву та ефективного руйнування при дезінтеграції.

Ключові слова: математичне моделювання, гірська порода, межа міцності, руйнування, тріщина, повна діаграма «напруження-деформація»

\section{Метод определения параметров диаграмм усеченно-клинового разрушения цилиндрических образцов горных пород}

\author{
Л. М. Васильев ${ }^{1}$, Д. Л. Васильев ${ }^{1}$, А. Е. Назаров ${ }^{1}$, \\ Н. Г. Малич², В.А. Катан
}


1 - Институт геотехнической механики имени Н. С. Полякова НАН Украины, г. Днепр, Украина

2 - Национальная металлургическая академия Украины, г. Днепр, Украина, e-mail: n22051957m@gmail.com

3 - Днепровский национальный университет имени О. Гончара, г. Днепр, Украина

Цель. Разработка аналитического метода расчета параметров полных диаграмм «продольное напряжение деформация» для усеченно-клиновой формы разрушения цилиндрических образцов породы для управления напряженно-деформированным состоянием горного массива и эффективного разрушения этих материалов при дезинтеграции.

Методика. Аналитически, путем разработки математической модели процесса разрушения цилиндрических образцов горных пород при их усеченно-клиновой форме развития трещин создать алгоритм расчета полной диаграммы деформирования от действующего напряжения с использованием экспериментальных значений четырех показателей свойств материалов - предела сопротивления сдвигу, коэффициентов внутреннего и внешнего трения и модуля упругости. В основу метода положен усовершенствованный критерий прочности Кулона, дополненный параметрами контактного трения и позволивший, с использованием теории линий скольжения, проводить расчет предельного состояния материала в вершине трещин, развивающихся из краев образца правильной геометрии с учетом выхода части материала из- под нагрузки и соответствия закону Гука деформации несущей площадки образца и удельным на неё усилием

Результаты. Метод математического моделирования позволяет определить предел прочности и остаточную прочность цилиндрических образцов горных пород с использованием четырех показателей свойств, которые простыми способами могут быть установлены экспериментально.

Научная новизна. Впервые проведено аналитическое моделирование процесса разрушения цилиндрических образцов горных пород при их усеченно-клиновой форме разрушения с учетом внутреннего, зависящего от свойств материала породы, и внешнего контактного трения.

Практическая значимость. Предложенный метод математического моделирования и алгоритм расчета позволяют определить предел и остаточную прочность образцов горных пород с использованием четырех показателей свойств, которые могут быть установлены экспериментально в условиях лабораторий предприятий горнометаллургического комплекса. Результаты расчета могут быть оперативно использованы для управления состоянием горного массива и эффективного разрушения при дезинтеграции.

Ключевые слова: математическое моделирование, горная порода, предел прочности, разрушение, трещина, полная диаграмма «напряжение - деформация»

Recommended for publication by S.P. Mineiev, Doctor of Technical Sciences. The manuscript was submitted 29.05.20. 